\title{
Chapter 20 \\ Article 25: The Right to Periodic Review of Treatment and All Other Circumstances of Placement
}

\author{
Gerison Lansdown and Ziba Vaghri
}

States Parties recognize the right of a child who has been placed by the competent authorities for the purposes of care, protection or treatment of his or her physical or mental health to a periodic review of the treatment provided to the child and all other circumstances relevant to his or her placement.

\section{What Did Children Say?}

'More in-depth screening process for foster parents to ensure the housing placement will be safe before the follow-up.' (Western Europe/Other)

'The point in my life at which I became a drug addict was about a year after I got on my Youth Agreement. Looking back on it, I think the reason why was because my social worker hadn't checked in with me in over 6 months, and I didn't have any other responsible adults in my life-no outreach workers, advocates, nothing.' (Western Europe/Other)

'Social workers have regularly visit and provide both mental and physical care.' (Asia-Pacific)

They should be taken to the hospital when they are ill and they must be given proper/great care. E.g., going to school wearing proper uniform, be given all they need at school and proper (diet). (Africa)

G. Lansdown $(\triangle)$

Carleton University, Ottawa, ON, Canada

Z. Vaghri

University of New Brunswick Saint John, Saint John, NB, Canada

e-mail: ziba.vaghri@unb.ca 


\section{Overview}

Article 25 introduces a right for children, who have been placed by competent authorities for the purposes of care, protection, or treatment, to have treatment of their physical or mental health reviewed on a periodic basis. An earlier draft included reference to emotional health which was subsequently removed, although in practice, the term mental health is probably sufficiently broad to encompass emotional health (UN Commission on Human Rights, 1986, para. 60; Office of the United Nations High Commissioner for Human Rights \& Rädda barnen (Society: Sweden), 2007, p. 605).

Article 25 was introduced into the Convention in recognition of the need for children, placed away from home, to be subject to independent oversight. The foresight of the drafters in anticipating the imperative for such protection has been highlighted since, in light of the widespread recent evidence that, without oversight and scrutiny, children placed away from home can be exposed to significant neglect and abuse, while individuals and institutions all too frequently fail to protect children's best interests. ${ }^{1}$ The aim of Article 25 is to provide a mechanism to protect children and ensure oversight into their circumstances by requiring regular reviews to ascertain, for example, the appropriateness of placement, the quality of care, the goals for treatment and planning, and the progress of treatment plans (Hodgkin et al., 2007, p. 379; UN General Assembly, 2010).

Article 25 specifies that the obligation to undertake reviews applies to all forms of placement in private and public care and treatment facilities provided that they are undertaken by competent authorities. States Parties have overall responsibility for determining the standards necessary to be acknowledged as a competent authority. Beyond these parameters, Article 25 is not prescriptive as to the nature, form, content, or frequency of those reviews. They are within the discretion of States Parties. However, the Alternative Care Guidelines do provide more detailed recommendations as to how reviews should be implemented (UN General Assembly, 2010). In addition, the Committee has recommended that States Parties apply the obligation to interpret Article 25 to cover both formal and informal placements in the widest possible range of settings (1999a, para. 21, 1999b, para. 22).

\footnotetext{
${ }^{1}$ See, for example, the Final Report of the Australian Royal Commission into Institutional Responses to Child Sexual Abuse, https://www.childabuseroyalcommission.gov.au/; Hidden Suffering: Romania's Segregation and Abuse of Infants and Children with Disabilities (Ahern \& Rosenthal, 2006), and The Pindown Experience and the Protection of Children: Report of the Staffordshire Child Care Enquiry (Levy \& Kahan, 1991).
} 


\section{General Principles}

Article 2 No differentiation in the quality or the frequency of the review process should be made on the basis of any of the prohibited grounds for discrimination. States Parties must ensure that they take all possible measures to identify and eliminate discrimination when assessing the appropriateness of placements and the ongoing need for care or treatment of any child who is the subject of a review (UN Committee on the Rights of the Child, 2003, para. 12, 2007, para. 8, 2013; UN Human Rights Committee, 1989; United Nations, 2003, p. 147).

Article 3 Periodic reviews, whether they be legislative, administrative or judicial, must be guided by, and ensure primary and explicit consideration to, the principle of the best interests of the child in respect of the care, protection, and treatment being provided. This principle must be applied in respect of all decisions and actions taken, directly or indirectly (UN Committee on the Rights of the Child, 2003, para. 12). Article 3 (3) complements Article 25 in that it ensures monitoring of institutions, systems, and staff, while Article 25 focuses on the individual circumstances of the child.

Article 6 Both the process and the ultimate aim of the review must be to respect and preserve the dignity of the child and their rights, while promoting outcomes that support their optimum health and development.

Article 12(2) The right of the child to be heard, either directly or through a representative, in any judicial or administrative proceeding affecting them, applies equally to periodic reviews. The Committee has emphasised that children should be provided with information about when, where, and how any review is to take place, and be afforded the opportunity to be present and to express their views. Children who are not able or willing to express a view are entitled have a representative to act on their behalf. The proceedings must be accessible and child friendly (UN Committee on the Rights of the Child, 2009a, paras. 65-66).

\section{Articles Related to or Linked to Article 25}

Article 5 requires that the evolving capacities of the child are taken into account within the review process.

Article 16 recognises the child's right to privacy and dignity throughout the review process.

Article 19 establishes the right to protection including for children placed for care, protection or treatment, as such children can be particularly vulnerable to abuse.

Article 20 is closely linked to Article 25 as all children who are provided with care by the State are entitled to periodic reviews of their placement. 
Article 22 addresses the right of children seeking asylum or considered a refugee and such children, placed by state in care, are entitled to periodic reviews in the same way as any other child.

Article 23 (1) focuses on the rights of children with disabilities, who are entitled to reviews of their care and treatment to address the efficacy and impact any institutional or other forms of care.

Article 39 provides that if a review process finds that the child's rights have been violated or neglected, there should be appropriate reparation, including compensation, and, where needed, measures introduced to promote physical and psychological recovery, rehabilitation and reintegration (UN Committee on the Rights of the Child, 2003, para. 24).

\section{Relevant Instruments}

UN Universal Declaration of Human Rights (1948), Articles 8 and 10 International Covenant on Civil and Political Rights (1966), Article 9

International Convention on the Elimination of All Forms of Racial Discrimination (1966), Article 6

UN Convention on the Elimination of All Forms of Discrimination against Women (1979), Article 2

UN Convention against Torture and Other Cruel, Inhuman or Degrading Treatment or Punishment (1984), Article 13

UN Convention on the Rights of Persons with Disabilities (2006), Article 12

\section{Attributes}

\section{Attribute One: Scope and Authorisation of Periodic Reviews}

Despite the more restrictive wording of Article 25 as applying specifically to those children placed for purposes of care, protection, or treatment, the Committee, in its earlier reporting guidelines, interpreted the obligations under Article 25 to extend to the widest possible range of care environments for children, including, for example, those placed as a consequence of homelessness, abandonment, asylum or refugee status, children in institutional care, and those in conflict with the law (1996). Certainly, it imposes an obligation on States Parties to ensure that any child needing a placement, without which they would suffer from a lack of care, protection, or physical or mental health treatment, must have their situation reviewed on a periodical basis.

Furthermore, the wording of Article 25 states that it applies only to those placements that have been made by a competent authority. Both public and private bodies can be recognised as competent authorities for this purpose. During the 
drafting of the Convention, a decision was made to remove reference to placement 'with competent State authorities,' presumably in acknowledgement that the provision should apply more widely to include private bodies (UN Commission on Human Rights, 1986, para. 60; Office of the United Nations High Commissioner for Human Rights \& Rädda barnen (Society: Sweden), 2007). However, the state should establish the legal standards for determining whether to grant an authority the legal competency to place a child, and the associated monitoring of compliance with those standards (UN General Assembly, 2010, paras. 23, 55). Despite the clear implication in the text of Article 25 that it applies only to children placed by competent authorities, the Committee has, at times, recommended to States Parties that they should introduce review mechanisms for children placed in informal forms of alternative care ${ }^{2}$

\section{Attribute Two: Periodicity and Content of Reviews of the Placement}

Article 25 does not define how frequently reviews should take place. The Alternative Care Guidelines suggest that a thorough review should be undertaken at least every 3 months (UN General Assembly, 2010, para. 67). However, the nature of the placement, its duration, and the needs of the children concerned will vary widely and will necessarily influence the periodicity with which they need to take place. The Committee has affirmed this approach arguing for decisions to be made on a case-bycase basis (2005, para. 667). Factors determining the frequency of reviews can include the individual circumstances of the child, and the importance of assessing both the necessity and the suitability of the placement (Cantwell et al., 2012).

No guidance is given by Article 25 about the content of the review process and by whom it should be undertaken. Tobin and Luke suggest that an effective system of review must ensure independent oversight of the institution, organisation, or individual with whom the child is placed, by individuals suitably qualified to perform the review (2019, p. 980). In terms of the content of the review, the wording of Article 25 makes clear that it needs to address not only the treatment of the child but also 'all other circumstances relevant to his or her placement.'

The Alternative Care Guidelines propose that reviews should address 'the appropriateness of his/her care and treatment, taking into account his or her family environment and the adequacy and necessity of the current placement' (UN General Assembly, 2010, para. 67). Persons undertaking the review must consider if the placement is reasonable, in terms of providing care, protection, or treatment, and whether there are other approaches that could avoid the need for alternative care. They must also consider the suitability of the placement in terms of

\footnotetext{
${ }^{2}$ See, for example, concluding observations for Guinea (1999a, para. 21) and Qatar (2009b, para. 46).
} 
its capacity to ensure respect for the rights of the child being cared for. Thus, consideration should be given to the quality of the environment, the extent to which the child's needs are being met, the provision of education, access to medical treatment as necessary, opportunities for play and recreation, and respect for the child's religion, culture and language. The review should also give consideration to the long-term needs of the child, with consideration given to the reintegration with their family, where appropriate, or to permanent placements to avoid frequent changes of settings (UN Committee on the Rights of the Child, 2006, para. 39, 2012, para. $47(\mathrm{e}))$.

\section{Attribute Three: Accountability and Transparency}

The Committee has highlighted that 'children's special and dependent status creates difficulties for them in pursuing remedies for breaches of their rights' (2003, para. 24). This vulnerability lends significance to the value and necessity for periodic reviews, and the need for the review process to be transparent, inclusive, and accountable. The Alternative Care Guidelines recommend that children should be involved, as well as all persons involved in the child's life, including parents, legal guardians, and potential foster carers and other caregivers (UN General Assembly, 2010, para. 6). While Article 12 does not insist that the child's views are determinative, the Committee has strongly recommended that just listening to the child is insufficient: the views of the child have to be seriously considered in all cases where when the child is capable of forming her or his own views (2009a, para. 28). Equally, it must be recognised that the child's participation in the review process is a right, not an obligation. They should be provided with information about the review process, its purpose, who will be participating, location, and timing but they are entitled to choose to exclude themselves from the process, and should not be put under any pressure to take part against their wishes (UN Committee on the Rights of the Child, 2009a, para. 16). In all circumstances, they should be fully informed about the outcomes of the review.

Once a review has taken place, its findings must be fully implemented. However, if a child, or representative acting on the child's behalf, is dissatisfied with the outcome of the review, the failure to act on the findings, or, indeed, a failure to conduct a review, there should be a complaints mechanism in place through which the child can seek redress. Complaints mechanisms must be child friendly, expeditious with timely remedies, and offer a confidential process to encourage children to share their views and wishes and have their concerns appropriately resolved (UN Committee on the Rights of the Child, 2003, para. 24). 


\section{References}

Ahern, I., \& Rosenthal, E. (2006). Hidden suffering: Romania's segregation and abuse of infants and children with disabilities. Mental Disability Rights International. https://hsrc.himmelfarb. gwu.edu/books/196/

Cantwell, N., Davidson, J., Elsley, S., Milligan, I., \& Quinn, N. (2012). Moving Forward: Implementing the 'Guidelines for the Alternative Care of Children'. The Centre for Excellence for Looked After Children in Scotland. https://www.alternativecareguidelines.org/ MovingForward/tabid/2798/language/en-GB/Default.aspx

Hodgkin, R., Newell, P., \& UNICEF. (2007). Implementation handbook for the Convention on the Rights of the Child (3rd ed.). UNICEF. Retrieved September 21, 2020, from https:// digitallibrary.un.org/record/620060? $\mathrm{ln}=\mathrm{en}$

Levy, A., \& Kahan, B. (1991). The pindown experience and the protection of children: The report of the Staffordshire Child Care Inquiry 1990. Staffordshire County Council.

Office of the United Nations High Commissioner for Human Rights, \& Rädda barnen (Society: Sweden). (2007). Legislative history of the Convention on the Rights of the Child. United Nations. https://digitallibrary.un.org/record/602462? $1 \mathrm{n}=\mathrm{en}$

Tobin, J., \& Luke, E. (2019). Article 25: The right to periodic review. In J. Tobin (Ed.), The UN Convention on the Rights of the Child: A commentary (pp. 970-985). Oxford University Press.

UN Commission on Human Rights. (1986). Report of the working group on a Draft Convention on the Rights of the Child, 1986, E/CN.4/1986/39. UN. Retrieved October 23, 2020, from http:// digitallibrary.un.org/record/121490

UN Committee on the Rights of the Child. (1996). General Guidelines regarding the form and contents of periodic reports to be submitted by states parties under article 44, paragraph 1 (b) of the Convention, November 20, 1996, CRC/C/58. Retrieved October 12, 2020, from https://digitallibrary.un.org/record/230051? $\mathrm{ln}=\mathrm{en}$

UN Committee on the Rights of the Child. (1999a). Concluding observations: Guinea, May 10, 1999, CRC/C/15/Add.100. UN. Retrieved November 8, 2020, from http://digitallibrary.un. org/record/275070

UN Committee on the Rights of the Child. (1999b). Concluding observations: Chad, August 24, 1999, CRC/C/15/Add.107. UN. Retrieved November 8, 2020, from http://digitallibrary.un. org/record/286863

UN Committee on the Rights of the Child. (2003). General Comment No. 5 (2003) General measures of implementation of the Convention on the Rights of the Child (arts. 4, 42 and 44, para. 6), November 27, 2003, CRC/GC/2003/5. Retrieved October 12, 2020, from https:// digitallibrary.un.org/record/513415? $\mathrm{ln}=\mathrm{en}$

UN Committee on the Rights of the Child. (2005). Day of General Discussion: Children Without Parental Care. UN. Retrieved November 6, 2020, from https://www.ohchr.org/EN/HRBodies/ CRC/Pages/DiscussionDays.aspx

UN Committee on the Rights of the Child. (2006). Concluding observations: Azerbaijan, March 17, 2006, CRC/C/AZE/CO/2. Retrieved October 11, 2020, from https://digitallibrary.un.org/ record $/ 575654 ? \mathrm{ln}=\mathrm{en}$

UN Committee on the Rights of the Child. (2007). General Comment No. 9 (2006) The rights of children with disabilities, November 13, 2007, CRC/C/GC/9. Retrieved October 12, 2020, from https://digitallibrary.un.org/record/593891? $\mathrm{ln}=\mathrm{en}$

UN Committee on the Rights of the Child. (2009a). General Comment No. 12 (2009) The right of the child to be heard, July 20, 2009, CRC/C/GC/12. Retrieved October 12, 2020, from https:// digitallibrary.un.org/record/671444? $\mathrm{ln}=\mathrm{en}$

UN Committee on the Rights of the Child. (2009b). Concluding observations: Qatar, October 14, 2009, CRC/C/QAT/CO/2. UN. Retrieved November 8, 2020, from http://digitallibrary.un. org/record/669131 
UN Committee on the Rights of the Child. (2012). Concluding observations: Viet Nam, August 22, 2012, CRC/C/VNM/CO/3-4. UN. Retrieved November 8, 2020, from http://digitallibrary.un. org/record/732970

UN Committee on the Rights of the Child. (2013). General Comment No. 14 (2013) On the right of the child to have his or her best interests taken as a primary consideration (art. 3, para. 1), May 29, 2013, CRC/C/GC/14. Retrieved October 12, 2020, from https://digitallibrary.un.org/record/ $778523 ? \ln =\mathrm{en}$

UN General Assembly. (2010). Guidelines for the alternative care of children, 2010, A/RES/64/ 142. https://digitallibrary.un.org/record/673583? $\mathrm{ln}=\mathrm{en}$

UN Human Rights Committee. (1989). CCPR General Comment No. 18 (1989) Non-discrimination, November 21, 1989, CCPR/C/21/Rev.1/Add.1. https://digitallibrary.un. org/record $/ 84170 ? \mathrm{ln}=\mathrm{en}$

United Nations. (2003). Compilation of General Comments and General Recommendations adopted by human rights treaty bodies, HRI/GEN/1/Rev. 6. UN. Retrieved April 19, 2020, from https://digitallibrary.un.org/record/502688? $\ln =$ en

Open Access This chapter is licensed under the terms of the Creative Commons Attribution 4.0 International License (http://creativecommons.org/licenses/by/4.0/), which permits use, sharing, adaptation, distribution and reproduction in any medium or format, as long as you give appropriate credit to the original author(s) and the source, provide a link to the Creative Commons license and indicate if changes were made.

The images or other third party material in this chapter are included in the chapter's Creative Commons license, unless indicated otherwise in a credit line to the material. If material is not included in the chapter's Creative Commons license and your intended use is not permitted by statutory regulation or exceeds the permitted use, you will need to obtain permission directly from the copyright holder.

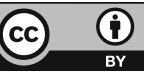

